\title{
Single dose of rituximab in children with steroid-dependent minimal change nephrotic syndrome
}

\author{
XIAO-LING NIU* ${ }^{*}$ SHENG HAO *, PING WANG, WEI ZHANG, GUI-MEI GUO, YING WU, \\ XIN-YU KUANG, GUANG-HUA ZHU and WEN-YAN HUANG \\ Department of Nephrology and Rheumatology, Children's Hospital of Shanghai, \\ Shanghai Jiaotong University, Shanghai 200062, P.R. China
}

Received March 15, 2016; Accepted June 27, 2016

DOI: $10.3892 /$ br.2016.711

\begin{abstract}
Rituximab (RTX) can be used in children with nephrotic syndrome, particularly in those with steroid-dependent nephrotic syndrome(SDNS). However, at present there is no unified standard of how to use RTX, with regard to the amount of doses and frequency, in children with nephrotic syndrome. The study aimed to investigate the therapeutic efficacy of a single dose of RTX in children with steroid-dependent minimal change nephrotic syndrome (SD-MCNS). The patients with biopsy-proven minimal change disease (MCD) and clinical features of SDNS received a single dose of RTX $\left(375 \mathrm{mg} / \mathrm{m}^{2}\right)$. The toxicity and side effects of RTX were also observed. The study included 19 patients (10 males and 9 females). Follow-up of the patients was 1-50 months (28.1 \pm 16.6 months). B-cell depletion was achieved with RTX infusion $($ CD20<0.5\%) and lasted 1-6 months (mean, 2.92 \pm 1.57 months). During follow-up, 10 patients remained in complete remission and did not relapse without administration of oral steroids or immunosuppressants for 4-50 months (mean, 30.1 \pm 12.6 months), despite recovery of the B-cell count. Nine patients relapsed in the process of reducing steroids, thus, treatment was maintained at a lower dosage $(\mathrm{T}=0, \mathrm{P}<0.05)$ than prior to use of RTX. The number of relapses also decreased significantly $(\mathrm{T}=95, \mathrm{P}<0.05)$. Five of the patients relapsed after stopping steroid for several months. At the end of follow-up, the efficacy of a single induction of RTX was $47.4 \%$ (9/19). There were no significant side effects associated with administration of RTX. In conclusion, RTX is a safe and effective alternative for children with SD-MCNS.
\end{abstract}

Correspondence to: Professor Wen-Yan Huang, Department of Nephrology and Rheumatology, Children's Hospital of Shanghai, Shanghai Jiaotong University, 355 Luding Road, Shanghai 200062, P.R. China

E-mail: huangwenyan@sjtu.edu.cn

*Contributed equally

Key words: rituximab, minimal change disease, steroid-dependent nephrotic syndrome, children, efficiency
RTX is an effective treatment for the rapid induction of remission and reduces relapse and steroid dependency. A single dose of RTX for children with SD-MCNS is recommended for rapid induction of remission, reduction of long-term steroid dosage, and decrease in the number of relapses, as it has few side effects.

\section{Introduction}

Idiopathic nephrotic syndrome is one of the most common kidney diseases found in children, with a prevalence of 1-3 out of 100,000 in those younger than 16 years of age (1). Clinically, nephrotic syndrome is characterized by massive proteinuria, edema, hypoalbuminemia and hyperlipidemia with heterogeneous histological features ranging from minimal change disease (MCD), focal segmental glomerulosclerosis and mesangial proliferative glomerulonephritis (MPGN) (1). MCD is the most common pathological form of pediatric nephrotic syndrome (1). The epidemiological data from the International Study of Kidney Disease in Children (ISKDC) have shown that approximately $93 \%$ of patients with MCD respond well to steroids, with a relapse rate as high as $80-90 \%$ (2). Long-term steroid treatment and immunosuppressants, such as calcineurin inhibitors, have been successful in the management of these patients but result in severe side effects (3).

Monoclonal antibody, rituximab (RTX), is a $35-\mathrm{kDa}$ protein highly expressed in B-lymphocytes from early to late B-cell stages, that inhibits CD20-mediated B-cell proliferation and differentiation (4). RTX was first introduced for the treatment of B-cell non-Hodgkin's lymphoma and was subsequently given to patients with autoimmune diseases, such as rheumatoid arthritis, lupus erythematosus, and immune complex-mediated glomerulonephritis (5). Previous findings showed that RTX is effective in maintaining remission in refractory steroid-dependent cases (6-10). Increased successful inductions of remission following RTX treatment in steroiddependent nephrotic syndrome (SDNS) or frequently relapsing nehprotic syndrome (FRNS) than in steroid-resistant nephrotic syndrome were previously reported (6-7). Anecdotal studies have indicated the induction of RTX in MCD is superior to focal segmental glomerulosclerosis (8). In addition, it was recently demonstrated that the median relapse-free period was longer in the RTX group than the placebo group in patients 
with SDNS or FRNS (9). However, the patients received RTX four times, and $42 \%$ of the patients had severe side effects (9). Thus, whether a single dose of RTX for the patients with SDNS or steroid-resistance nephrotic syndrome with fewer side effects of RTX remained to be determined. Fujinaga et al showed that a single dose of RTX allowed for a decreased dose of steroids in the management of MCD (10).

The aim of the present study was to investigate the efficiency and side effects of a single dose of RTX in the management of pediatric SDNS with a histological diagnosis of MCD.

\section{Materials and methods}

Subjects. Patients with SDNS who were hospitalized in the Children's Hospital of Jiaotong University from October 2011 to December 2015 were enrolled in the study. The patients were diagnosed with SDNS according to the Kidney Disease Improving Global Outcomes (KDIGO) guidelines and ISKDC criteria with biopsy-proven MCD $(11,12)$. All the patients had frequent relapses despite combined therapy with steroids and mycophenolate mofetil, cyclophosphamide or calcineurin inhibitors, tacrolimus (FK506) and cyclosporine A (CsA).

The patients with SDNS were excluded if they: i) Had no renal biopsy; ii) had renal biopsy but the pathology of renal was not MCD; and iii) were not administered with other immunosuppressants.

Diagnoses and outcomes of all the patients were according to the KDIGO guidelines and criteria (11): i) For nephrotic syndrome: Edema, urine protein/creatinine ratio (uPCR) $\geq 2,000 \mathrm{mg} / \mathrm{g}$ ( $\geq 300 \mathrm{mg} / \mathrm{mmol}$ ), or $\geq 300 \mathrm{mg} / \mathrm{dl}$, or $3^{+}$protein on the urine dipstick, hypoalbuminaemia $\leq 2.5 \mathrm{~g} / \mathrm{dl}$; ii) complete remission: uPCR $<200 \mathrm{mg} / \mathrm{g}(<20 \mathrm{mg} / \mathrm{mmol})$ or $<1^{+}$of protein on the urine dipstick for 3 consecutive days; iii) partial remission: Proteinuria reduction of $\geq 50 \%$ from the presenting value and absolute uPCR between 200 and $2,000 \mathrm{mg} / \mathrm{g}$ (20-200 $\mathrm{mg} / \mathrm{mmol})$; iv) no remission: failure to reduce urine protein excretion by $50 \%$ from baseline or persistent excretion uPCR $2,000 \mathrm{mg} / \mathrm{g}(200 \mathrm{mg} / \mathrm{mmol})$; and v) relapse: uPCR $\geq 2,000 \mathrm{mg} / \mathrm{g}(\geq 200 \mathrm{mg} / \mathrm{mmol})$ or $\geq 3^{+}$protein on urine dipstick for 3 consecutive days.

Patients with SDNS were defined as having at least two relapses during steroid tapering every other day or within 14 days after discontinuation according to the ISKDC criteria (12). RTX induced B-lymphocyte depletion was defined as a CD20 count $<0.5 \%$ of the total lymphocyte count $(9,13)$. RTX efficiency was defined as complete remission lasting for $\geq 6$ months after RTX until the end of follow-up without the administration of steroids or other immunosuppressants.

Protocol. A written consent form was obtained from all the patients for the indication and side effects of RTX. A single dose of RTX $\left(375 \mathrm{mg} / \mathrm{m}^{2}\right)$ was administered. Phenergan and dexamethasone were administered as premedications prior to infusion. After RTX, the patients only taking steroids decreased rapidly after complete remission was achieved, and use of steroids ceased in 1-3 months depending on the various doses of steroids.

Follow-up. Follow-up on patients occurred at day 3, week 2, months 1,3 and 6 , and one year after RTX infusion.
Laboratory data including complete blood count, urinalysis, liver and kidney function tests, immunoglobulin levels, and lymphocyte fractionation were obtained prior to RTX infusion and at follow-up visits. All the patients were followed-up for $\geq 6$ months.

Methods. Blood was collected in an ETDA-anticoagulation tube and tested immediately for CD20 (CD20 L27 and CD45-PC5; BD Biosciences, Franklin Lakes, NJ, USA) and lymphocyte fractionation (BD Multitest ${ }^{\mathrm{TM}}$ IMK kit; BD Biosciences) using a flow cytometer (BD FACSCalibur ${ }^{\mathrm{TM}}$; BD Biosciences). The blood count was tested using an automatic blood cell analyzer. Urinalysis was tested using a urine analyzer. Liver and kidney function tests were tested using a automatic biochemistry analyzer. Immunoglobulin was tested using the immune transmission turbidity method.

Statistical analysis. Data were presented as mean \pm standard deviation. Comparisons before and following RTX infusion were carried out using the Wilcoxon matched-pairs signed rank test. The correlation between different indices was studied using the Spearman's correlation analysis. $\mathrm{P}<0.05$ was considered statistically significant.

\section{Results}

Patient characteristics. Nineteen patients (10 males and 9 females) with MCD, with an age range of 5-17 years (mean, 8.21 \pm 2.99 years) were included in the present study. The maintenance dose of steroids was $6.82-32.1 \mathrm{mg} / \mathrm{m}^{2} / \mathrm{day}$ $\left(13.7 \pm 7.12 \mathrm{mg} / \mathrm{m}^{2} /\right.$ day). The course of disease prior to RTX was 18-108 months (52.7 \pm 27.1 months). The patient follow-up was $1-50$ months ( $28.1 \pm 16.6$ months). Pretreatment features of the patients are listed in Table I. Prior to RTX infusion, all the patients relapsed more than two times with steroids and immunosupressants.

RTX infusion. Following RTX infusion, B-cell depletion $(\mathrm{CD} 20<0.5 \%)$ was achieved and lasted for 1-6 months (mean, $2.92 \pm 1.57$ months). The variability of B-cells is shown in Fig. 1. To the end of follow-up, 10 patients remained in complete remission and did not relapse following a single dose of RTX infusion for 4-50 months (mean, 30.1 \pm 12.6 months) despite recovery of the B-cell (CD20) count. During steroid tapering, 9 patients relapsed within 2-21 months (mean, $7.67 \pm 6.26$ months) of RTX infusion, and 4 of them relapsed after steroids were ceased for several months. However, the maintenance dose of steroids and relapse rate within 12 months were less than those prior to RTX treatment ( $\mathrm{T}=0$, $\mathrm{P}<0.05 ; \mathrm{T}=95, \mathrm{P}<0.05)$. No correlation between relapses and B-cell count $(r=-0.194, P>0.05)$ was observed. Details of the 9 patients who relapsed are shown in Table II.

The efficacy of a single induction of RTX was 47.4\% (9/19). Details of patients after RTX are presented in Table III.

Side effects of RTX. One patient developed a rash during the infusion of RTX with transient tachycardia (130 bpm) and tachypnea (35 times/min). The patient had no fever or anaphylaxis and the rash improved by retarding the infusion. Another patient complained of transient dizziness during the infusion. 
Table I. Clinical characteristics of patients prior to RTX infusion.

\begin{tabular}{|c|c|c|c|c|c|c|c|c|}
\hline $\begin{array}{l}\text { Patient } \\
\text { no. }\end{array}$ & Gender & $\begin{array}{c}\text { Age } \\
\text { (years) }\end{array}$ & $\begin{array}{l}\text { Years } \\
\text { since } \\
\text { onset }\end{array}$ & $\begin{array}{c}\text { Immunosuppressant } \\
\text { before RTX }\end{array}$ & $\begin{array}{l}\text { Relapse } \\
\text { rate/year }\end{array}$ & $\begin{array}{l}\text { Prednisone dose } \\
\text { before RTX infusion } \\
(\mathrm{mg} / \mathrm{kg} / \text { day })\end{array}$ & $\begin{array}{c}\text { Dependent-steroid } \\
\text { dosage }\left(\mathrm{mg} / \mathrm{m}^{2} / \text { day }\right)\end{array}$ & $\begin{array}{l}\text { Urine } \\
\text { protein }\end{array}$ \\
\hline 1 & $\mathrm{~F}$ & 6 & 4 & MMF, CTX, FK506 & 3 & 0.5 & 17.5 & +++ \\
\hline 2 & M & 6 & 4.5 & MMF, CTX & 4 & 0.4 & 10.5 & - \\
\hline 3 & $\mathrm{~F}$ & 11 & 8 & MMF, CTX, FK506 & 5 & 1.0 & 30.0 & ++ \\
\hline 4 & M & 17 & 6 & MMF, CTX, CsA & 4 & 0.28 & 9.55 & ++ \\
\hline 5 & M & 11 & 9 & MMF, CTX & 3 & 0.22 & 7.4 & +++ \\
\hline 6 & $\mathrm{~F}$ & 8 & 3 & $\mathrm{CsA}$ & 3 & 0.23 & 8.45 & + \\
\hline 7 & M & 9 & 7.5 & CsA & 2 & 0.43 & 13.5 & +++ \\
\hline 8 & $\mathrm{~F}$ & 9 & 6 & MMF & 2 & 0.22 & 6.82 & +++ \\
\hline 9 & M & 8 & 3.5 & $\mathrm{CsA}$ & 3 & 0.35 & 12.1 & +++ \\
\hline 10 & $\mathrm{~F}$ & 7 & 5 & MMF, CTX, FK506 & 4 & 0.77 & 14.4 & +++ \\
\hline 11 & $\mathrm{~F}$ & 6 & 3 & CsA & 2 & 0.78 & 8.89 & ++ \\
\hline 12 & M & 5 & 4 & MMF, CsA & 3 & 0.69 & 8.77 & +++ \\
\hline 13 & M & 5 & 2 & FK506 & 2 & 1.25 & 32.1 & +++ \\
\hline 14 & M & 7 & 4 & CsA & 2 & 0.35 & 11.5 & - \\
\hline 15 & M & 10 & 2.5 & MMF, FK506 & 4 & 0.41 & 18.2 & +++ \\
\hline 16 & $\mathrm{~F}$ & 6.5 & 5 & FK506, MMF & 3 & 1.46 & 9.15 & ++ \\
\hline 17 & $\mathrm{~F}$ & 6.5 & 4.5 & $\mathrm{MMF}, \mathrm{CsA}$ & 3 & 0.57 & 13.0 & +++ \\
\hline 18 & $\mathrm{~F}$ & 6 & 2.5 & CTX & 2 & 0.78 & 19.5 & ++ \\
\hline 19 & M & 12 & 10 & FK506 & 2 & 0.39 & 8.93 & - \\
\hline
\end{tabular}

RTX, rituximab; F, female; M, male; MMF, mycophenolate mofetil; CTX, cyclophosphamide; FK506, tacrolimus; CsA, cyclosporine A.

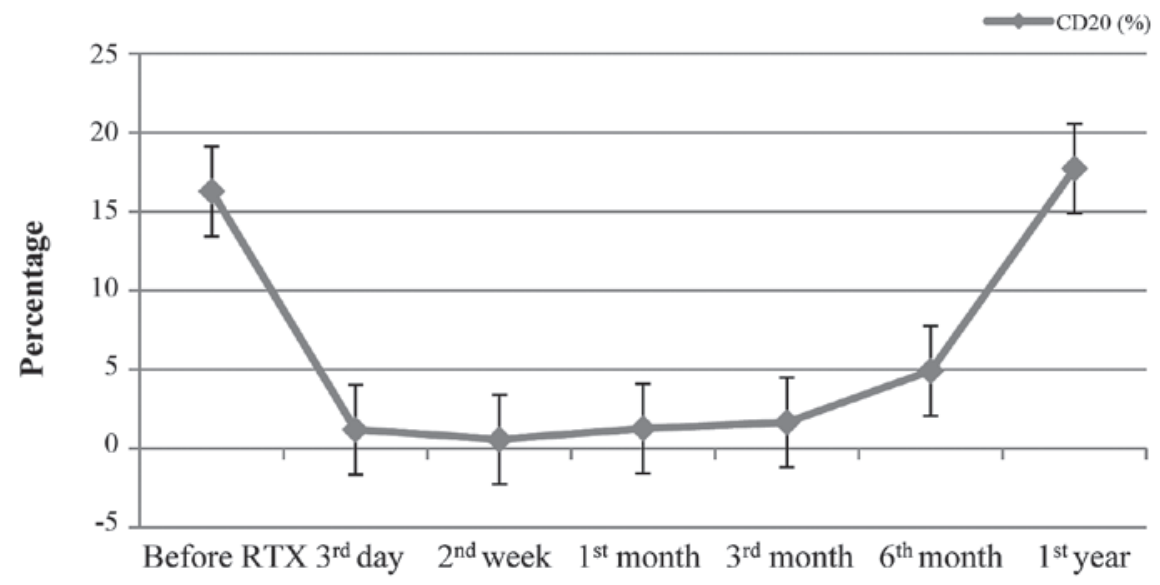

Figure 1. CD20 before and after infusion of RTX. The '3rd day', '2nd week', '1st month', '3rd month', '6th month' and '1st year' were all the days after the infusion of RTX. RTX, rituximab.

The remaining patients tolerated the infusion well without complications.

Studies available on RTX in children with SDNS or FRNS. There are several studies with regard to RTX administration in children $(6,7,9,10,13-20)$. The information is presented in Table IV. The noted cases of steroid-sensitive nephrotic syndrome relapsed more than two times so were classified as SDNS.

\section{Discussion}

Steroid dependency poses a challenge in the treatment of MCD in pediatric nephrotic syndrome. Long-term use and a 
Table II. Patient relapse following RTX infusion.

Patient no.

\begin{tabular}{lccccccccc}
\cline { 2 - 7 } Relapse & 2 & 3 & 4 & 5 & 7 & 9 & 10 & 15 & 16 \\
\hline Relapse-free duration (months) & 2 & 4 & 10 & 21 & 5 & 3 & 14 & 6 & 4 \\
Cause of relapse & Infection & No & Infection & No & No & No & Infection & No & Infection \\
Steroid dosage on relapse (mg/kg/day) & 5.26 & 1.88 & 3.05 & No & No & 2.02 & No & No & 0.13 \\
Time to second relapse (months) & 19 & 19 & 20 & - & - & 9 & - & - \\
Cause of relapse & No & No & Rabies vaccine & - & - & Infection & - & - & - \\
Steroid dosage on relapse (mg/kg/day) & 3.95 & 7.52 & No & - & - & 4.05 & - & - \\
\hline
\end{tabular}

RTX, rituximab.

Table III. Clinical characeristics of patients following RTX infusion.

\begin{tabular}{|c|c|c|c|c|c|c|c|}
\hline $\begin{array}{l}\text { Patient } \\
\text { no. }\end{array}$ & $\begin{array}{l}\text { RTX } \\
\text { dose }\end{array}$ & $\begin{array}{l}\text { Prednisone dose } \\
\quad(\mathrm{mg} / \mathrm{kg} / \text { day })\end{array}$ & $\begin{array}{l}\text { Dependent-steroid } \\
\text { dose }\left(\mathrm{mg} / \mathrm{m}^{2} / \text { day }\right)\end{array}$ & $\begin{array}{l}\text { Urine } \\
\text { protein }\end{array}$ & $\begin{array}{l}\text { Relapse } \\
\text { rate/year }\end{array}$ & $\begin{array}{l}\text { Follow-up } \\
\text { (months) }\end{array}$ & $\begin{array}{l}\text { Drugs used now } \\
\quad(\mathrm{mg} / \mathrm{kg} / \text { day })\end{array}$ \\
\hline 1 & 1 & 0 & - & - & 0 & 50 & No \\
\hline 2 & 1 & 0.08 & 3.95 & - & 2 & 50 & Pred 0.08 \\
\hline 3 & 1 & 0.1 & 1.88 & - & 2 & 47 & Pred 0.1 \\
\hline 4 & 1 & 0.09 & 3.05 & - & 2 & 45 & Pred 0.17 \\
\hline 5 & 1 & 0 & - & - & 1 & 41 & No \\
\hline 6 & 1 & 0 & - & - & 0 & 40 & No \\
\hline 7 & 1 & 0 & 13.5 & - & 1 & 37 & Pred 0.5, MMF \\
\hline 8 & 1 & 0 & - & - & 0 & 34 & No \\
\hline 9 & 1 & 0.05 & 2.02 & - & 2 & 34 & Pred 0.02 \\
\hline 10 & 1 & 0 & - & - & 1 & 31 & No \\
\hline 11 & 1 & 0 & - & - & 0 & 30 & No \\
\hline 12 & 1 & 0 & - & - & 0 & 25 & No \\
\hline 13 & 1 & 0 & - & - & 0 & 24 & No \\
\hline 14 & 1 & 0 & - & - & 0 & 22 & No \\
\hline 15 & 1 & 0.29 & 4.46 & - & 1 & 10 & Pred 0.4 \\
\hline 16 & 1 & 0.13 & 1.41 & - & 1 & 7 & Pred 1.04 \\
\hline 17 & 1 & 0 & - & - & 0 & 4 & No \\
\hline 18 & 1 & 0.20 & - & - & 0 & 1 & Pred 0.2 \\
\hline 19 & 1 & 0.20 & - & - & 0 & 1 & Pred 0.2 \\
\hline
\end{tabular}

RTX, rituximab; Pred, prednisone; MMF, mycophenolate mofetil.

high dose of steroids and immunosuppressants cause severe side effects (3). Thus, oral agent-free treatment is an attractive therapeutic approach for patients with nephrotic syndrome (21).

The role of B lymphocytes in the pathogenesis of MCD, a T-cell, has been previously considered to play a key role (22-26). Previous findings have shown that CD23 increased in patients with nephrotic syndrome $(22,23)$. Interleukin- 13 , a cytokine associated with type 2 T-helper cells, leads to antibody production and allergic reactions caused by immune responses involving B-cells in patients with nephrotic syndrome $(24,25)$. B-cells are essential in CD4 T-cell activation for antigen presenting and providing co-stimulation signals (26). Tokunaga et al (4) showed that RTX decreases CD40- and CD80-expressing cells in activated $\mathrm{B}$-cells in patients with systemic lupus erythematosus and downregulates CD40L and CD69 on CD4-positive cells. The successful induction of remission following RTX treatment in some cases of MCD provides evidence supporting the hypothesis that the interference of B- and T-cells is a potential strategy for MCD treatment $(8,10)$.

In our clinical study, patients receiving RTX treatment presented an outcome of fewer relapses, longer relapse-free periods and reduced maintenance doses of steroids. Patients 
Table IV. Studies available on RTX administration in children with SDNS or FRNS.

\begin{tabular}{|c|c|c|c|c|c|c|}
\hline Study (author, year) & No. of cases & Time of RTX & Follow-up & Co-drugs & Efficiency (\%) & Refs. \\
\hline Iijima et al, 2014 & $\begin{array}{c}24 \\
\text { FRNS/SDNS }\end{array}$ & $\begin{array}{l}375 \mathrm{mg} / \mathrm{m}^{2} / \mathrm{time} \\
\text { Once a week } \\
\text { for } 4 \text { weeks }\end{array}$ & 53 weeks & Pred & $14 / 24(58.3)$ & (9) \\
\hline Sun et al, 2014 & $\begin{array}{l}9 \text { for SSNS } \\
2 \text { for SRNS }\end{array}$ & $\begin{array}{l}375 \mathrm{mg} / \mathrm{m}^{2} / \mathrm{time} \\
\text { One or two times }\end{array}$ & 4-16 months & Pred & $5 / 9(55.6)$ & (14) \\
\hline Ravani et al, 2013 & $\begin{array}{c}46 \\
\text { SDNS }\end{array}$ & $\begin{array}{l}375 \mathrm{mg} / \mathrm{m}^{2} / \mathrm{time} \\
\text { One to five times }\end{array}$ & $>3$ years & Pred and CsA & $22 / 46(48.0)$ & (6) \\
\hline Ito et al, 2013 & $\begin{array}{c}53 \\
\text { SDNS/FRNS }\end{array}$ & $\begin{array}{l}375 \mathrm{mg} / \mathrm{m}^{2} / \mathrm{time} \\
\text { One or more times }\end{array}$ & 8-51 months & Pred or CsA & $41 / 53(77.0)$ & $(15)$ \\
\hline Tellier et al, 2013 & $\begin{array}{c}18 \\
\text { SDNS }\end{array}$ & $\begin{array}{l}375 \mathrm{mg} / \mathrm{m}^{2} / \mathrm{time} \\
\text { One to four times }\end{array}$ & Median 3.2 years & Pred & $8 / 18(44.5)$ & (16) \\
\hline Sellier-Leclerc et al, 2012 & $\begin{array}{c}30 \\
\text { SDNS }\end{array}$ & $\begin{array}{l}375 \mathrm{mg} / \mathrm{m}^{2} / \mathrm{time} \\
\text { One to four times }\end{array}$ & $>24$ months & Pred or MMF or CsA & $19 / 30(63.3)$ & (17) \\
\hline Kemper et al, 2012 & $\begin{array}{l}29 / 37 \\
\text { SDNS }\end{array}$ & $\begin{array}{l}375 \mathrm{mg} / \mathrm{m}^{2} / \mathrm{time} \\
\text { Once a week } \\
\text { for } 1 \text { to } 4 \text { weeks }\end{array}$ & $>24$ months & Pred or CI or MPI & $7 / 29(24.1)$ & (18) \\
\hline Ravani et al, 2011 & $\begin{array}{c}54 \\
\text { SDNS }\end{array}$ & $\begin{array}{l}375 \mathrm{mg} / \mathrm{m}^{2} / \mathrm{time} \\
\text { One or two times }\end{array}$ & $>9$ months & Pred and CsA & $27 / 54(50.0)$ & (19) \\
\hline Fujinaga et al, 2010 & $\begin{array}{c}10 \\
\text { MCD, SDNS }\end{array}$ & $\begin{array}{l}375 \mathrm{mg} / \mathrm{m}^{2} / \mathrm{time} \\
\text { One time }\end{array}$ & 17 months & CsA & $5 / 10(50.0$ & $(10)$ \\
\hline Sellier-Leclerc et al, 2010 & $\begin{array}{c}22 \\
\text { SDNS }\end{array}$ & $\begin{array}{l}375 \mathrm{mg} / \mathrm{m}^{2} / \mathrm{time} \\
\text { One or two times }\end{array}$ & 3.2-28.5 months & Pred or CsA & $9 / 22(41.0)$ & (20) \\
\hline Prytuła et al, 2010 & $\begin{array}{c}28 \\
\text { SDNS/FRNS }\end{array}$ & $\begin{array}{l}375 \mathrm{mg} / \mathrm{m}^{2} / \mathrm{time} \\
\text { One to five times }\end{array}$ & $1-16$ months & Pred & $10 / 28(35.7)$ & (13) \\
\hline Kamei et al, 2009 & $\begin{array}{c}12 \\
\text { SDNS }\end{array}$ & $\begin{array}{l}375 \mathrm{mg} / \mathrm{m}^{2} / \mathrm{time} \\
\text { One time }\end{array}$ & $>12$ months & Pred & $3 / 12(25.0)$ & (7) \\
\hline
\end{tabular}

RTX, rituximab; FRNS, frequently relapsing nephrotic syndrome; SDNS, steroid-dependent nephrotic syndrome; SSNS, steroid-sensitive nephrotic syndrome; SRNS, steroid-resistance nephrotic syndrome; MPA, mycophenolic acid; Pred, prednisone; CI, calcineurin inhibitors.

remained relapse-free despite the recovery of B-cell count, indicating that RTX treatment may regulate the immunity of patients and induce remission by inhibiting B-cells. B-cell depletion by RTX may block T-cell activation induced by B-cells or B-cell-derived factors resulting in a change of T-cell cytokine production responsible for the development of idiopathic nephrotic syndrome. B-cell depletion by RTX may also change regulatory $\mathrm{T}$-cell functions, inducing changes in $\mathrm{T}$ - and B-cell cytokine production (18). Further studies are needed to confirm this hypothesis.

One to four doses of RTX were used to achieve and maintain complete remission in children with SDNS or FRNS in most clinical studies $(6,7,9,10,13-20)$. The actual regimen of RTX may require adjustment in an individualized manner, depending on the response and actual clinical condition. In the present study, RTX efficacy on MCD in children with SDNS was $47.4 \%$ (9/19). Other studies showed efficacy to be between 25 and $77 \%$ with several doses of RTX. This result shows that a single dose of RTX can achieve a comparable outcome in the management of pediatric MCD, with a favorable cost-benefit ratio and a decrease in side effects.

In conclusion, RTX is a safe and effective alternative for MCD forms of SDNS in children. For patients with severe side effects from steroid treatment or those who cannot tolerate immunosuppressants, RTX is an effective treatment in the rapid induction of remission, reducing relapses and steroid dependence. We recommend a single dose of RTX for children with steroid-dependent minimal change nephrotic syndrome for the rapid induction of remission, reduction on long-term steroid dose and decreasing the number of relapses, and having fewer side effects. Larger samples of randomized controlled clinical trials are required to justify the definite efficacy and safety of RTX in this group of patients.

\section{Acknowledgements}

The present study was supported by the Chinese National Natural Science Foundation (grant no. 81370813 awarded to 
Professor Wen-Yan Huang) and the Program for Outstanding Subject Leaders of Shanghai Health Bureau Foundation (grant no. XBR 2011010 awarded to Professor Wen-Yan Huang).

\section{References}

1. McKinney PA, Feltbower RG, Brocklebank JT and Fitzpatrick MM: Time trends and ethnic patterns of childhood nephrotic syndrome in Yorkshire, UK. Pediatr Nephrol 16: 1040-1044, 2001.

2. Tarshish P, Tobin JN, Bernstein J and Edelmann CM Jr: Prognostic significance of the early course of minimal change nephrotic syndrome: report of the International Study of Kidney Disease in Children. J Am Soc Nephrol 8: 769-776, 1997.

3. Hodson EM, Willis NS and Craig JC: Non-corticosteroid treatment for nephrotic syndrome in children. Cochrane Database Syst Rev 1: CD002290, 2008.

4. Tokunaga M, Saito K, Kawabata D, Imura Y, Fujii T, Nakayamada S, Tsujimura S, Nawata M, Iwata S, Azuma T, et al: Efficacy of rituximab (anti-CD20) for refractory systemic lupus erythematosus involving the central nervous system. Ann Rheum Dis 66: 470-475, 2007.

5. Iijima K: Rituximab for childhood refractory nephrotic syndrome. Pediatr Int 53: 617-621, 2011.

6. Ravani P, Ponticelli A, Siciliano C, Fornoni A, Magnasco A, Sica F, Bodria M, Caridi G, Wei C, Belingheri M, et al: Rituximab is a safe and effective long-term treatment for children with steroid and calcineurin inhibitor-dependent idiopathic nephrotic syndrome. Kidney Int 84: 1025-1033, 2013.

7. Kamei K, Ito S, Nozu K, Fujinaga S, Nakayama M, Sako M, Saito M, Yoneko M and Iijima K: Single dose of rituximab for refractory steroid-dependent nephrotic syndrome in children. Pediatr Nephrol 24: 1321-1328, 2009.

8. Gulati A, Sinha A, Jordan SC, Hari P, Dinda AK, Sharma S, Srivastava RN, Moudgil A and Bagga A: Efficacy and safety of treatment with rituximab for difficult steroid-resistant and -dependent nephrotic syndrome: Multicentric report. Clin J Am Soc Nephrol 5: 2207-2212, 2010.

9. Iijima K, Sako M, Nozu K, Mori R, Tuchida N, Kamei K, Miura K, Aya K, Nakanishi K, Ohtomo Y, et al; Rituximab for Childhood-onset Refractory Nephrotic Syndrome (RCRNS) Study Group: Rituximab for childhood-onset, complicated, frequently relapsing nephrotic syndrome or steroid-dependent nephrotic syndrome: a multicentre, double-blind, randomised, placebo-controlled trial. Lancet 384: 1273-1281, 2014.

10. Fujinaga S, Hirano D, Nishizaki N, Kamei K, Ito S, Ohtomo Y, Shimizu T and Kaneko K: Single infusion of rituximab for persistent steroid-dependent minimal-change nephrotic syndrome after long-term cyclosporine. Pediatr Nephrol 25: 539-544, 2010.

11. Kidney Disease Improving Global Outcomes: KDIGO Clinical Practice Guideline for Glomerulonephritis. Kidney Int Suppl 2: 139-274, 2012.

12. Schulman SL, Kaiser BA, Polinsky MS, Srinivasan R and Baluarte HJ: Predicting the response to cytotoxic therapy for childhood nephrotic syndrome: superiority of response to corticosteroid therapy over histopathologic patterns. J Pediatr 113 996-1001, 1988.
13. Prytuła A, Iijima K, Kamei K, Geary D, Gottlich E, Majeed A, Taylor M, Marks SD, Tuchman S, Camilla R, et al: Rituximab in refractory nephrotic syndrome. Pediatr Nephrol 25: 461-468, 2010.

14. Sun L, Xu H, Shen Q, Cao Q, Rao J, Liu HM, Fang XY and Zhou LJ: Efficacy of rituximab therapy in children with refractory nephrotic syndrome: a prospective observational study in Shanghai. World J Pediatr 10: 59-63, 2014.

15. Ito S, Kamei K, Ogura M, Udagawa T, Fujinaga S, Saito M, Sako M and Iijima K: Survey of rituximab treatment for childhood-onset refractory nephrotic syndrome. Pediatr Nephrol 28: 257-264, 2013.

16. Tellier S, Brochard K, Garnier A, Bandin F, Llanas B, Guigonis V, Cailliez M,Pietrement C, Dunand O, Nathanson S, et al: Long-term outcome of children treated with rituximab for idiopathic nephrotic syndrome. Pediatr Nephrol 28: 911-918, 2013.

17. Sellier-Leclerc AL, Baudouin V, Kwon T, Macher MA, Guérin V, Lapillonne H, Deschênes $G$ and Ulinski T: Rituximab in steroid-dependent idiopathic nephrotic syndrome in childhood - follow-up after CD19 recovery. Nephrol Dial Transplant 27: 1083-1089, 2012.

18. Kemper MJ, Gellermann J, Habbig S, Krmar RT, Dittrich K, Jungraithmayr T, Pape L, Patzer L, Billing H, Weber L, et al: Long-term follow-up after rituximab for steroid-dependent idiopathic nephrotic syndrome. Nephrol Dial Transplant 27: 1910-1915, 2012.

19. Ravani P, Magnasco A, Edefonti A, Murer L, Rossi R, Ghio L, Benetti E, Scozzola F, Pasini A, Dallera N, et al: Short-term effects of rituximab in children with steroid- and calcineurin-dependent nephrotic syndrome: a randomized controlled trial. Clin J Am Soc Nephrol 6: 1308-1315, 2011.

20. Sellier-Leclerc AL, Macher MA, Loirat C, Guérin V, Watier H, Peuchmaur M, Baudouin V and Deschênes G: Rituximab efficiency in children with steroid-dependent nephrotic syndrome. Pediatr Nephrol 25: 1109-1115, 2010.

21. El-Reshaid K, Sallam HT, Hakim AA and Al-Attiyah R: Rituximab in treatment of idiopathic glomerulopathy. Saudi J Kidney Dis Transpl 23: 973-978, 2012.

22. Samarghitean C, Väliaho J and Vihinen M: Online registry of genetic and clinical immunodeficiency diagnostic laboratories, IDdiagnostics. J Clin Immunol 24: 53-61, 2004.

23. Kyrieleis HA, Löwik MM, Pronk I, Cruysberg HR, Kremer JA, Oyen WJ, van den Heuvel BL, Wetzels JF and Levtchenko EN: Long-term outcome of biopsy-proven, frequently relapsing minimal-change nephrotic syndrome in children. Clin J Am Soc Nephrol 4: 1593-1600, 2009.

24. Kemper MJ, Meyer-Jark T, Lilova M and Müller-Wiefel DE: Combined T- and B-cell activation in childhood steroid-sensitive nephrotic syndrome. Clin Nephrol 60: 242-247, 2003.

25. Cho BS, Yoon SR, Jang JY, Pyun KH and Lee CE: Up-regulation of interleukin-4 and CD23/FcepsilonRII in minimal change nephrotic syndrome. Pediatr Nephrol 13: 199-204, 1999.

26. Kimata H, Fujimoto M and Furusho K: Involvement of interleukin (IL)-13, but not IL-4, in spontaneous IgE and IgG4 production in nephrotic syndrome. Eur J Immunol 25: 1497-1501, 1995. 